\title{
PERANCANGAN USER REQUIREMENTS SPECIFICATION (URS) SISTEM OTOMASI UNTUK PROSES CHAMFER STOPPER VALVE PADA MESIN BENCH LATHE SD-32A DI PT DHARMA PRECISION PARTS
}

\author{
${ }^{1}$ Amalia Syafitri, ${ }^{2}$ Rino Andias Anugraha, ${ }^{3}$ Haris Rachmat \\ ${ }^{1,2,3}$ Program Studi Teknik Industri, Fakultas Rekayasa Industri, Telkom University \\ 19amaliasyafitri59@gmail.com, ${ }^{2}$ pak.rino@gmail.com, ${ }^{3}$ haris.bdg23@yahoo.com
}

\begin{abstract}
Abstrak-PT Dharma Precision Parts merupakan perusahaan manufaktur yang memproduksi komponen yang terbuat dari logam melalui proses pemesinan, salah satu produknya adalah stopper valve. Karena meningkatnya persaingan dan permintaan, perusahaan harus mampu mengurangi waktu proses untuk memenuhi permintaan. Waktu proses pada sistem awal yaitu sekitar $9.92 \mathrm{detik} /$ part. Perusahaan melakukan modifikasi mesin Bench Lathe SD-32A untuk mengurangi waktu proses dengan menerapkan teknologi otomasi. Menerapkan teknologi otomatisasi dalam perusahaan akan mendapatkan beberapa keuntungan seperti mengurangi waktu proses, meningkatkan kapasitas produksi dan kualitas produk. Penerapan sistem otomasi membutuhkan perencanaan yang baik dan pertimbangan untuk mendapatkan sistem baru sesuai dengan fungsi yang diharapkan dan untuk mencegah terjadinya perancangan ulang pada sistem.

Penelitian ini fokus pada perancangan User Requirement Specification (URS) yang terdiri dari kumpulan informasi kebutuhan untuk perancangan sistem otomasi pada industri manufaktur. Perancangan URS terdiri dari process description, deskripsi aliran listrik pada setiap peralatan yang saling terhubung, dan control philosophy. Berdasarkan hasil penelitian maka dapat disimpulkan bahwa perancangan URS untuk stopper valve chamfering proses berhasil diimplementasikan dengan mendapatkan waktu proses baru yaitu sekitar 5 detik/part. Hasil dari penelitian ini adalah penjelasan mengenai deskripsi proses, electrical diagram, dan control philosophy.
\end{abstract}

Kata kunci: user requirement specification, process description, electrical diagram, control philosophy

\section{PENDAHULUAN}

Industri manufaktur mempunyai tujuan untuk memenuhi permintaan dengan cara memproduksi produk secara produktif untuk mendapatkan keuntungan. Saat ini, tujuan tersebut dapat dicapai dengan menggunakan teknologi otomasi. Sebagian besar aktivitas yang dikerjakan oleh pekerja secara manual digantikan dengan teknologi otomasi sehingga dapat mengurangi waktu produksi, meningkatkan fleksibilitas produksi, mengurangi biaya tenaga kerja, dan mengeliminasi human error [1].

PT Dharma Precision Parts merupakan salah satu perusahaan manufaktur di Indonesia yang memproduksi komponen logam melalui proses permesinan dan juga memasok produknya kepada perusahaan OEM (Original Equipment Manufacturer). PT Dharma Precision Parts memiliki banyak mesin produksi dan berbagai jenis produk yang dihasilkan. Salah satu proses produksinya yaitu proses chamfer untuk membuat produk stopper valve. Proses chamfer dilakukan di mesin Bench Lathe SD-32A dimulai dengan menjepit komponen stopper valve yang sudah diproduksi sebelumnya di mesin Computer Numerical Control (CNC) pada spindel collet kemudian mengaktifkan motor untuk memutar spindel collet tersebut, ketika spindel collet berputar majukan pahat secara manual dengan memutar tuas untuk melakukan proses chamfer.

Dikarenakan adanya peningkatan kompetisi pada industri manufaktur maka perusahaan harus meningkatkan kapasitas dan kualitas produksinya sehingga perusahaan dapat memenuhi permintaan. Saat ini perusahaan memiliki masalah pada proses produksi stopper valve yaitu waktu proses yang terlalu lama dan tidak konsistennya lama waktu proses pada setiap pekerja dikarenakan proses chamfer stopper valve masih dilakukan oleh operator secara manual sehingga proses produksinya sangat dipengaruhi oleh human factor yang mengakibatkan berbedanya jumlah produksi yang dihasilkan. Waktu proses pada sistem awal dapat dilihat pada Tabel I dan rata-rata produk yang dihasilkan yaitu sebanyak 6 unit/menit. Jika kondisi ini tidak segera diperbaiki dengan cara mengurangi waktu proses maka perusahaan akan mengalami kerugian dikarenakan tidak dapat meningkatkan kapasitas produksinya.

Berdasarkan masalah yang ada, perusahaan perlu memodifikasi mesin yang digunakan untuk proses chamfer 
sehingga dapat mempercepat waktu proses produksi dan meningkatkan kapasitas. Memodifikasi mesin dilakukan karena tidak memerlukan waktu yang lama pada untuk membuatnya dibandingkan dengan membuat mesin yang baru selain itu dengan memodifikasi mesin yang ada dapat meningkatkan utilitas mesin tersebut.

TABEL IV

DATA PRODUKSI PADA KONDISI AWAL

\begin{tabular}{|l|l|}
\hline Parameter & Number \\
\hline Waktu proses & 9.92 detik/pcs \\
\hline 1 jam produksi & $362 \mathrm{pcs}$ \\
\hline Kebutuhan tenaga kerja & 1 operator/shift \\
\hline Rata-rata produksi & $2525 \mathrm{pcs} / \mathrm{shift}$ \\
\hline
\end{tabular}

Modifikasi mesin dilakukan pada mesin yang digunakan untuk proses chamfer yaitu mesin Bench Lathe SD-32A dengan cara menerapkan teknologi otomasi. Otomasi merupakan teknologi yang menerapkan sistem mekanik, listrik, dan komputer untuk mengoperasikan dan mengendalikan proses operasi [2]. Perancangan sistem otomatitasi pada mesin Bench Lathe SD-32A membutuhkan perencanaan dan pertimbangan yang baik sehingga dapat menjalankan fungsinya sesuai dengan yang diharapkan. Menurut American Principle, ada tiga langkah untuk menerapkan sistem otomasi. Pertama adalah mengetahui proses yang ada, yang kedua adalah membuat proses yang ada menjadi lebih sederhana, dan yang terakhir adalah menerapkan proses menggunakan sistem otomasi. Sebagai perusahaan manufaktur yang akan menggunakan sistem otomasi maka harus mengetahui kebutuhan sistem otomasi tersebut sehingga perancangan sistem otomasi dapat diterapkan sesuai dengan yang diharapkan. Salah satu metode yang digunakan untuk mengetahui kebutuhan sistem otomasi yaitu perancangan User Requirements Specification (URS). Perancangan URS terdiri dari process description, deskripsi aliran listrik yang terhubung antara masing-masing peralatan, dan control philosophy [3]. Perancangan URS juga digunakan sebagai dasar untuk membuat sistem otomatisasi.

Berdasarkan latar belakang tersebut, tujuan pada penelitian ini adalah merancang User Requirements Specification (URS) sistem otomasi untuk proses chamfer stopper valve pada mesin Bench Lathe SD-32A untuk mengurangi waktu proses produksi dan meningkatkan kualitas produk.

\section{USER REQUIREMENTS SPECIFICATION (URS)}

Penelitian dimulai dengan tahap identifikasi pada objek penelitian. Identifikasi dilakukan dengan cara pemngamatan langsung ke lantai produksi, setelah pengamatan dilakukan maka dapat didefinisikan permasalah yang terjadi pada kondisi awal. Ketika menganalisis sistem awal dilakukan juga studi literature untuk mendapatkan metode penelitian yang akan digunakan untuk memecahkan permasalahan yang ada. Pada penelitian ini metode yang sesuai untuk memecahkan masalah yang ada adalah metode User Requirements Specification (URS) sistem otomasi untuk proses chamfer stopper valve pada mesin Bench Lathe SD-32A. Input yang digunakan pada penelitian ini adalah waktu proses kondisi awal, proses chamfer pada kondisi awal, spesifikasi komponen yang akan diproduksi, kebutuhan pengguna untuk proses otomasi, dan kondisi awal mesin Bench Lathe SD-32A.

User Requirements Specification (URS) sistem otomasi digunakan untuk memberikan Gambaran secara jelas tentang kebutuhan yang diperlukan untuk sistem yang dirancang. URS harus dibuat dalam bentuk yang dapat dipahami oleh pemasok sistem atau integrator [3]. URS yang digunakan untuk menafsirkan kebutuhan sistem kontrol otomasi terdiri dari process description, control philosophy, dan electrical diagram. Process description memberikan Gambaran dasar untuk pemasok tentang proses yang ada pada sistem yang dirancang sehingga pemasok mendapatkan informasi tentang kebutuhan untuk mengendalikan proses tersebut. Control philosophy merupakan pernyataan yang berisi informasi mengenai pemilihan equipment yang akan digunakan pada sistem dan juga informasi mengenai fungsi serta spesifikasi equipment tersebut. Electrical diagram merupakan Gambar yang merepresentasikan rangkaian listrik pada sistem yang dirancang [4]. Electrical diagram terdiri dari wiring diagram dan schematic diagram.

Process Description

Process description pada sistem usulan untuk mesin Bench Lathe SD-32A diGambarkan menggunakan flow chart yang dapat dilihat pada Gambar 2, 3, dan 4. Berikut ini merupakan skenario sistem usulan proses chamfer stopper valve di PT Dharma Precision Parts :

1. System preparation

Proses ini merupakan proses awal sebelum dilakukan produksi produksi yang berfungsi untuk memastikan kondisi sistem dalam keadaan aman sehingga sistem dapat berjalan sesuai dengan yang diharapkan dan mencegah terjadinya kecelakaan kerja.

2. Inspection process

Proses inspeksi merupakan proses pertama yang dilakukan sebelum dilakukannya proses chamfer dengan memisahkan produk yang cacat agar tidak diproses lagi. Proses inspeksi ini dilakukan dengan secara otomatis dengan menggunakan sensor fotoelektrik.

3. Chamfering process

Stopper valve yang lolos dalam pemerikasaan akan masuk ke dalam slider kemudian stopper valve tersebut diantarkan ke depan collet menggunakan linear motion. Setelah stopper valve berapa di depan collet kemudian piston silinder part positioning mendorong stopper valve tersebut sampai menempel pada collet. Setelah itu stopper valve yang telah menempel pada collet dijepit dengan mendorong tuas clamping. Jika stopper valve telah terjepit dengan posisi yang benar pada collet dan sistem berada pada kondisi aman maka maka linear 
motion akan kembali ke posisi semula dan motor AC akan aktif untuk memutar collet, kemudian drilling shaft akan maju sampai mengenai stopper valve untuk melakukan proses chamfer.

Control Philosophy

Control philosophy merupakan deskripsi pemilihan hardware yang digunakan pada sistem otomasi. Spesifikasi hardware yang digunakan pada sistem usulan dapat dillihat pada Tabel II.

\section{Electrical Diagram}

Electrical diagram perancangan sistem otomasi proses chamfer stopper valve pada mesin Bench Lathe SD-32A diGambarkan menggunakan pneumatic schematic diagram dan electro pneumatic schematic diagram untuk mengilustrasikan aliran listrik yang terkoneksi anatar equipment menggunakan software Fluidsim. Electriacal diagram dapat dilihat pada Gambar 5 dan 6.

\section{HASIL DAN PEMBAHASAN}

Sistem awal proses chamfer stopper valve di PT Dharma Precision Parts masih menggunakan sistem konvensional yang menyebabkan lamanya waktu proses sehingga kapasitas produksi tidak dapat memenuhi permintaan dan kualitas produk tidak konsisten. Cara yang digunakan untuk meningkatkan kapasitas produksi yaitu dengan cara menerapkan teknologi otomasi dengan memanfaatkan teknologi pneumatic, sedangkan untuk menjaga kualitas produk dilakukan dengan cara melakukan pemeriksaan produk secara otomatis sebelum proses chamfer.

Process description yang dibuat pada sistem usulan digunakan untuk memberikan penjelasan kepada stakeholder mengenai aliran proses yang terjadi pada sistem usulan tersebut yang dimulai dari proses pemeriksaan produk sampai proses chamfer untuk memproduksi stopper valve sesuai dengan spesifikasinya.

Penentuan spesifikasi hardware dibutuhkan sehingga hardware yang terpasang pada sistem otomasi dapat menjalankan sistem sesuai dengan fungsinya. Selain itu, jika spesifikasi hardware yang dipasang tidak sesuai maka akan menimbulkan konsleting pada sistem, ketidak sesuaian jarak pendeteksian, dan lain sebagainya. Terpat beberapa variable yang perlu dipertimbangkan pada saat pemilihan spesifikasi hardware. Salah satu variable yang perlu dipertimbangkan yaitu daya listrik yang digunakan pada proses chamfer stopper valve, perbandingan antara kondisi awal dengan spesifikasi hardware yang akan diterapkan, serta posisi pemasangan hardware yang akan digunakan pada sistem usulan tersebut. Perancangan electrical diagram digunakan untuk mengetahui konfigurasi dari setiap equipment yang terpasang pada sistem otomasi proses chamfer stopper valve.

TABEL V

SPESIFIKASI HARDWARE YANG DIGUNAKAN PADA SISTEM USULAN

\begin{tabular}{|c|c|c|}
\hline No & Hardware & Spesifikasi \\
\hline 1 & Through beam sensor & $\begin{array}{l}\text { Jarak pendeteksian : } 200 \mathrm{~mm} \\
\text { Current consumption : max } 40 \mathrm{~mA} \\
\text { Supply voltage: } 12-24 \mathrm{VDC}\end{array}$ \\
\hline 2 & $\begin{array}{l}\text { Inductive proximity } \\
\text { sensor }\end{array}$ & $\begin{array}{l}\text { Jarak pendeteksian : } 8 \mathrm{~mm} \\
\text { Current consumption : max. } 10 \mathrm{~mA} \\
\text { Supply voltage: } 12-24 \mathrm{VDC}\end{array}$ \\
\hline 3 & Reed switch & $\begin{array}{l}\text { Jarak pendeteksian: } 7 \mathrm{~mm} \\
\text { Current consumption : } 10 \mathrm{~mA} \\
\text { Supply voltage: } 24 \mathrm{VDC}\end{array}$ \\
\hline 4 & Counter & $\begin{array}{l}\text { Jenis : Digital counter } \\
\text { Supply voltage }: 24 \mathrm{VDC} \\
\text { Konsumsi daya }: \pm 4 \mathrm{Watt}\end{array}$ \\
\hline 5 & AC Electrical Motor & $\begin{array}{l}\text { Jenis : Motor induksi tiga fasa } \\
\text { Kecepatan : } 2200 \mathrm{rpm} \\
\text { Torsi: } 6.6 \mathrm{lb} / \mathrm{ft} \\
\text { Daya }: 1.5 \mathrm{Kw}\end{array}$ \\
\hline 6 & Cylinder & $\begin{array}{l}\text { Jenis : Double dan single acting } \\
\text { cylinder }\end{array}$ \\
\hline 7 & Solenoid valve & $\begin{array}{l}\text { Jenis: } 5 / 2 \text { way valve dan } 3 / 2 \text { way } \\
\text { valve }\end{array}$ \\
\hline 8 & $\begin{array}{l}\text { Programmable Logic } \\
\text { Controller (PLC) }\end{array}$ & $\begin{array}{l}\text { Jenis PLC : PLC Omron CJ2M } \\
\text { CPU12 } \\
\text { Kuantitas : } 1 \text { unit } \\
\text { I/O modul : } 34 \text { input digital dan } 23 \\
\text { outputs digital. } \\
\text { Operating voltage }: 220 \mathrm{VAC} \\
\text { Current consumption }: 1.5 \mathrm{~A}\end{array}$ \\
\hline 9 & Air compressors & $\begin{array}{l}\text { Jenis : Reciprocating air compressors } \\
\text { Daya }: 1.5 \mathrm{HP}=1119 \mathrm{Watt} \\
\text { Operating voltage }: 380 \mathrm{VAC} \\
\text { Current consumption }: 3.7 \mathrm{~A}\end{array}$ \\
\hline 10 & Alarm (Buzzer) & $\begin{array}{l}\text { Jenis : Buzzer } \\
\text { Operating voltage : } 24 \mathrm{VDC} \\
\text { Current consumption : } 0.02 \mathrm{~A}\end{array}$ \\
\hline 11 & Tower Lamp & $\begin{array}{l}\text { Jenis : Industrial tower lamp } 3 \\
\text { module stack colors } \\
\text { Operating voltage : } 240 \text { VAC } \\
\text { Current consumption : } 0.19 \mathrm{~A} \\
\end{array}$ \\
\hline 12 & $\begin{array}{l}\text { Miniature Circuit } \\
\text { Breaker (MCB) }\end{array}$ & $\begin{array}{l}\text { Electric currents rating }: 6 \mathrm{~A} \\
\text { Voltage rating }: 230 \mathrm{~V}\end{array}$ \\
\hline 13 & Relay & $\begin{array}{l}\text { Jenis : Omron MY2 } \\
\text { Operating voltage : } 24 \mathrm{~V} \\
\text { Rated current : } 36.9 \mathrm{~mA} \\
\end{array}$ \\
\hline 14 & Contactor & $\begin{array}{l}\text { Jenis : Magnetic contactor AC } 3 \text { Pole } \\
\text { Rated operational power : } 380-400 \\
\text { VAC } \\
\text { Current rating : } 9 \mathrm{~A}\end{array}$ \\
\hline 15 & $\begin{array}{l}\text { Vibratory } \\
\text { Feeder }\end{array}$ & $\begin{array}{l}\text { Input voltage : } 220 \mathrm{VAC}, 60 \mathrm{~Hz} \\
\text { Beban daya : } 80 \mathrm{~mA}\end{array}$ \\
\hline
\end{tabular}




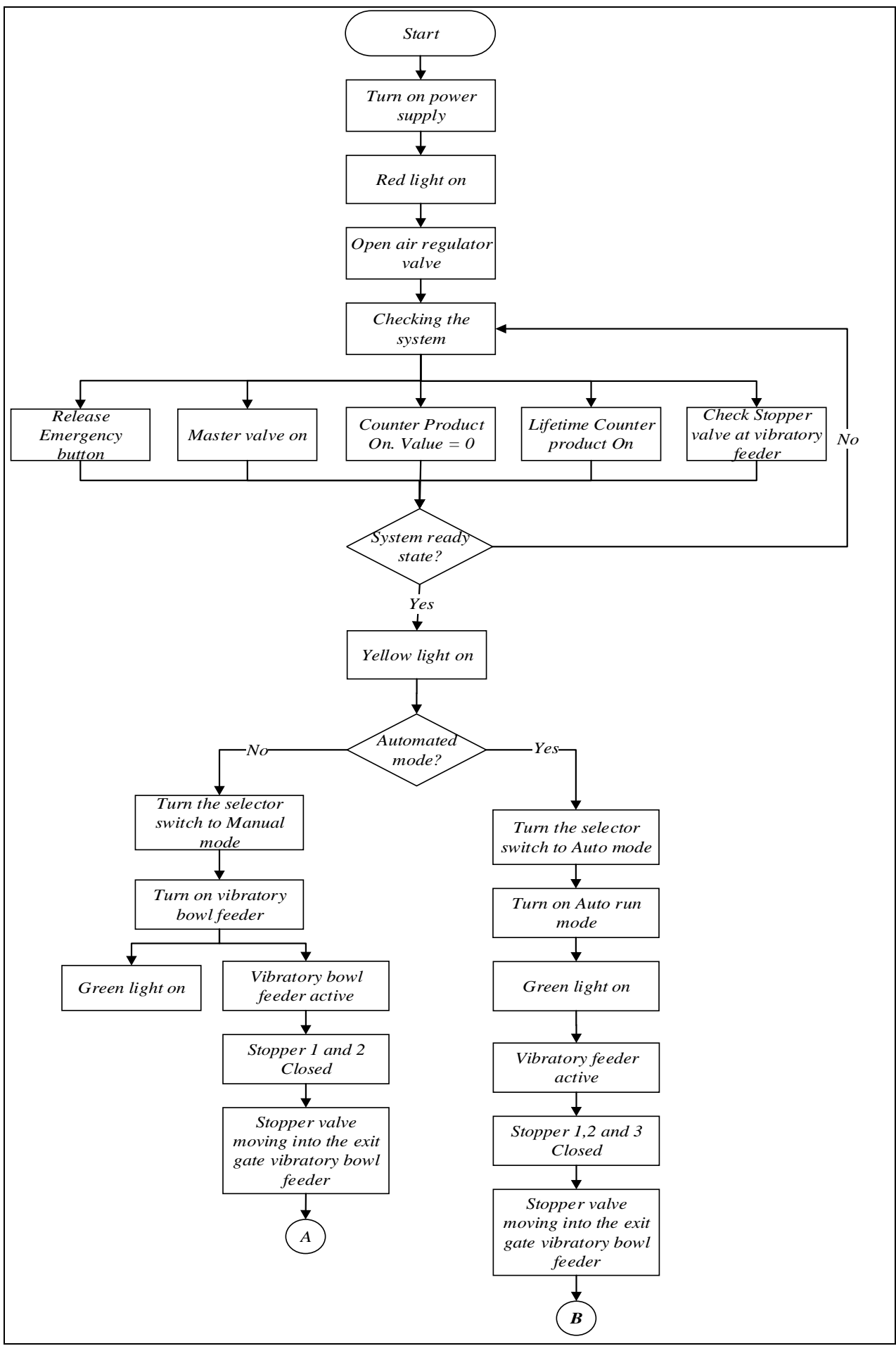

Gambar 21 Process description sistem usulan proses chamfer stopper valve pada mesin Bench Lathe SD-32A

Perancangan User Requirements Specification (URS) Sistem Otomasi untuk Proses Chamfer Stopper Valve 


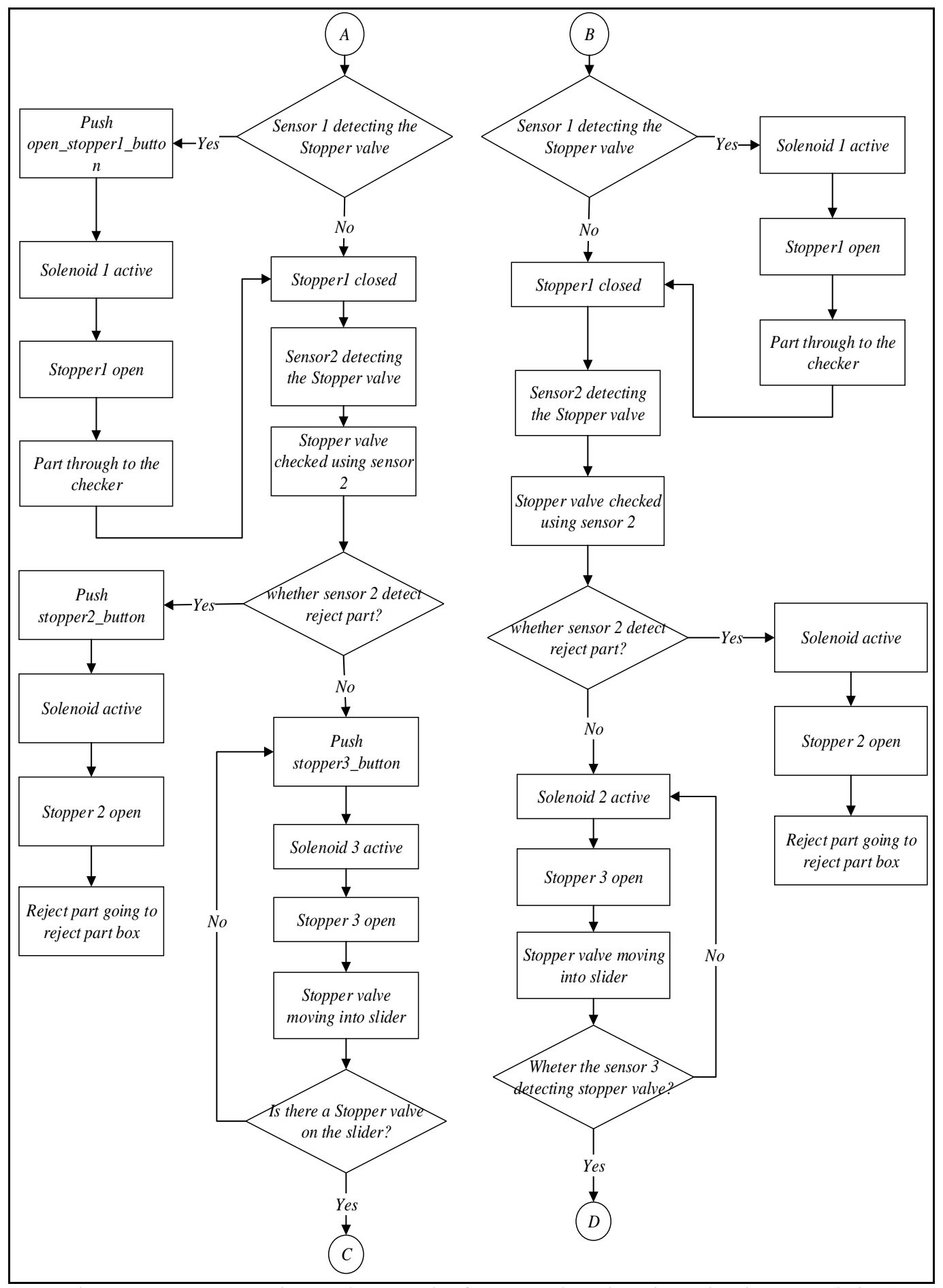

Gambar 22 Process description sistem usulan proses chamfer stopper valve pada mesin Bench Lathe SD-32A (lanjutan) 


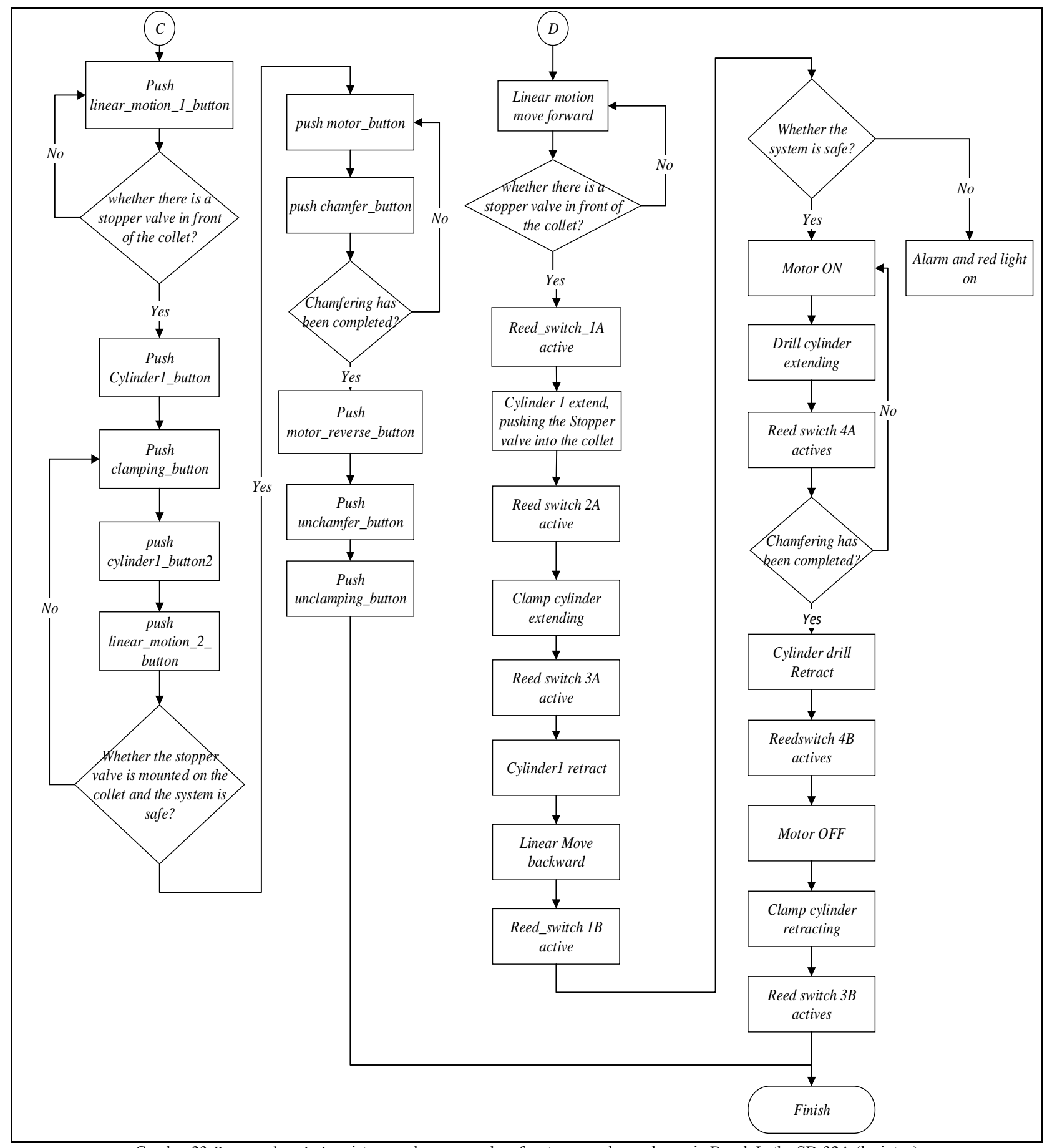

Gambar 23 Process description sistem usulan proses chamfer stopper valve pada mesin Bench Lathe SD-32A (lanjutan)

Perancangan User Requirements Specification (URS) Sistem Otomasi untuk Proses Chamfer Stopper Valve 


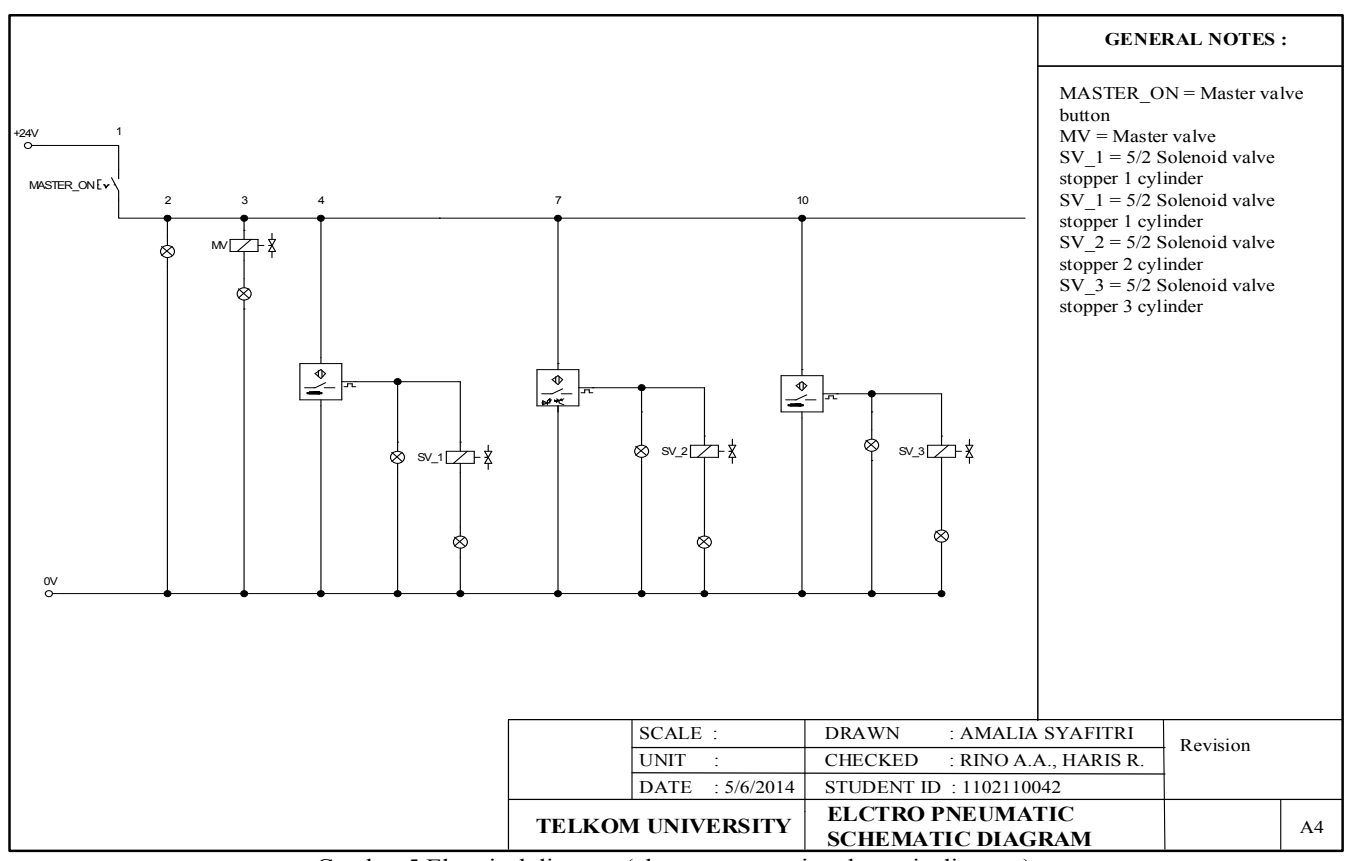

Gambar 5 Electrical diagram (electro pneumatic schematic diagram)

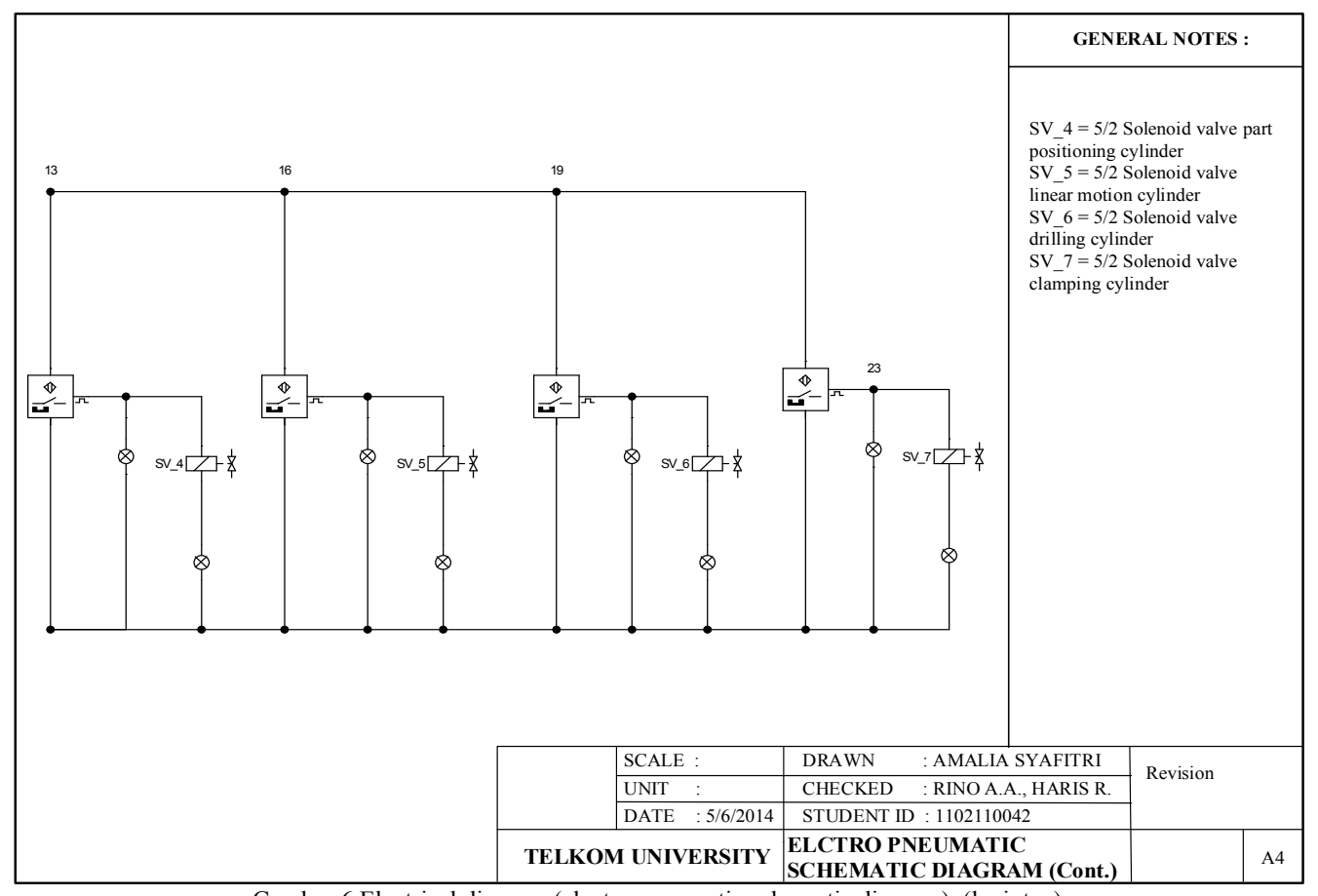

Gambar 6 Electrical diagram (electro pneumatic schematic diagram) (lanjutan)

Dengan penggambaran electrical diagram, maka stakeholder dapat memahami dengan jelas aliran listrik pada sistem. Pada proses chamfer stopper valve digambarkan dua jenis electrical diagram, yaitu pneumatic schematic diagram yang merupakan deskripsi dari sistem pneumatik yang digunakan pada sistem dan electro pneumatic schematic diagram yang merupakan deskripsi hubungan antara komponen elektrik dengan sistem penumatik yang 
terpasang pada sistem.

Perancangan URS sistem otomasi berhasil diimplementasikan dengan membuat process description, control philosophy, dan electrical diagram sehingga sistem otomasi dapat berjalan sesuai dengan yang diharapkan yaitu untuk mengurangi waktu proses. Perbandingan waktu proses sebelum dan setelah diterapkannya sistem otomasi pada proses chamfer stopper valve dapat dilihat pada Gambar 7 .

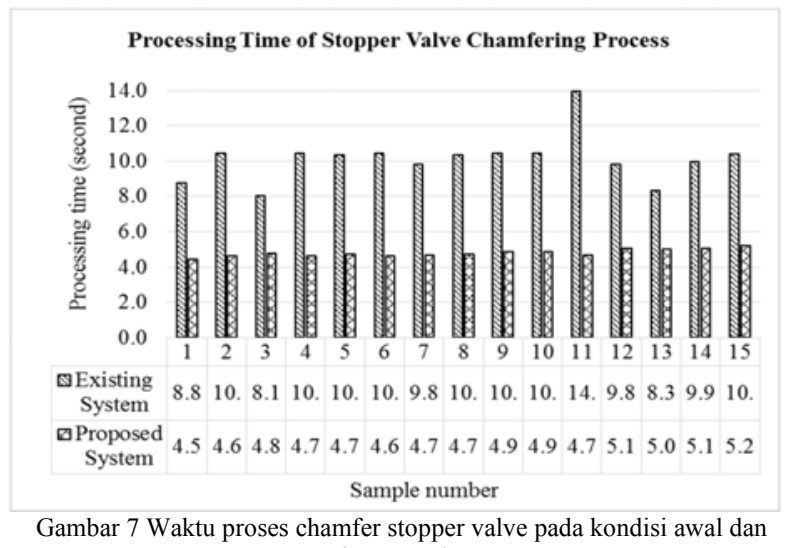
sistem usulan

Pengurangan waktu proses dapat meningkatkan kapasitas produksi sehingga dapat meningkatkan juga pendapatan. Perbandingan kondisi awal produksi dengan sistem usulan dapat dilihat pada Tabel III.

TABEL VI

PERBANDINGAN KONDISI PRODUKSI

\begin{tabular}{|l|c|c|}
\hline & $\begin{array}{c}\text { Sistem usulan } \\
\text { (Automation) }\end{array}$ & $\begin{array}{c}\text { Sistem awal } \\
\text { (Manual) }\end{array}$ \\
\hline Working time/shift (detik) & 25200 & 25200 \\
\hline Jumlah shift per hari & 3 & 3 \\
\hline Waktu produksi (detik/pcs) & 5 & 9.92 \\
\hline Jumlah produksi per shift (pcs) & 5040 & 2525 \\
\hline Jumlah produksi per hari (pcs) & 15120 & 7575 \\
\hline Jumlah produksi pertahun $(p c s)$ & 3931200 & 1969500 \\
\hline Pendapatan per tahun & Rp393,120,000 & Rp196,950,000 \\
\hline Keuntungan per tahun & Rp78,624,000 & Rp39,390,000 \\
\hline
\end{tabular}

Berdasarkan hasil perhitungan, keuntungan yang diperoleh pada sistem usulan lebih tinggi dibandingkan dengan sistem awal sehingga payback period sistem usulan yaitu sistem yang sudah diotomasikan lebih cepat dibandingkan dengan sistem awal. Berikut merupakan perhitungan payback period sistem usulan :

Payback period (tahun) $=$ Investasi/(keuntungan per tahun)

Payback period $($ tahun $)=43.842 .000 / 78.624 .000$

Payback period $\quad=0.6$ tahun

Payback period $\quad=6.7$ bulan

Berdasarkan perhitungan [5] tersebut dapat disimpulkan bahwa waktu yang dibutuhkan untuk mengembalikan biaya yang digunakan untuk investasi modifikasi mesin Bench Lathe SD-32A yaitu selama 6.7 bulan.

\section{KESIMPULAN}

Berdasarkan penelitian yang telah dilakukan, maka dapat disimpulkan bahwa perancangan User Requirement Specification (URS) sistem otomasi yang terdiri dari process description, control philosophy, dan electrical diagram yang digunakan sebagai dasar untuk merancang sistem otomasi untuk proses chamfer stopper valve pada mesin Bench Lathe SD-32A di PT Dharma Precision Parts berhasil diimplementasikan dengan mengurangi waktu proses yang semula waktunya $9.92 \mathrm{detik} /$ part menjadi $5 \mathrm{detik} /$ part dengan mengambil sampel sebanyak 100 kali, sehingga dengan itu dapat dikatan bahwa memodifikasi mesin dapat menurunkan waktu proses sebesar $45.5 \%$.

Process description terdiri dari deskripsi skenario proses yang terjadi pada sistem usulan yang menerapkan teknologi otomasi. Pada process description dijelaskan juga mengenai proses tambahan yang diusulkan seperti proses pemeriksaan produk yang dilakukan sebelum proses chamfer. Control philosophy merupakan deskripsi spesifikasi hardware yang digunakan pada sistem usulan dan identifikasi alamat input dan output yang akan digunakan pada pemrograman PLC. Electrical diagram digunakan untuk menjelaskan aliran listrik yang terhubung pada setiap peralatan yang terpasang pada sistem usulan. User Requirements Specification (URS) juga digunakan sebagai dasar untuk perancangan sistem pengendalian otomatis proses chamfer stopper valve pada mesin Bench Lathe SD-32A di PT Dharma Precision Parts.

\section{DAFTAR PUSTAKA}

[1] http://www.referenceforbusiness.com/small/ABo/Automation.html, diakses Januari 2015.

[2] Groover, M. P., Automation, Production Systems, and Computer-Integrated Mnufacturing, Pearson Prentice Hall, New Jerset, 2008.

[3] Love, J., Process Automation Handbook : A Guide to Theory and Practice, Springer, London, 2007.

[4] Raina, Batthacarya., Electrical Design Estimating and Costing, New Age International, New Delhi, 1991.

[5] Rangkuti, F., Studi Kelayakan Bisnis dan Investasi, Gramedia Pustaka Utama, Jakarta, 2012

Perancangan User Requirements Specification (URS) Sistem Otomasi untuk Proses Chamfer Stopper Valve 